\title{
DAMPAK PENDIDIKAN MASYARAKAT PADA PERUBAHAN AKHLAK REMAJA
}

\author{
Irfan Ahmad Zain ${ }^{1)}$, Mismit Husen²) \\ Program Pascasarjana (PPS) Universitas Islam Negeri (UIN) Sunan Gunung Djati \\ Bandung \\ e-mail: mismithusen88@gmail.com
}

\begin{abstract}
This paper aims to reveal how far the influence of public education on the moral changes of adolescents both on the attitude and mental. This issue is expressed using case studies. The selected case is the case in the community in Kampung Cisanggarung, Bandung regency. Data were collected through interview, observation and documentation study and analyzed by Miles and Huberman method which was founded by the theory of Prophet Muhammad's morals. The results showed that community education is very important role to change the morals and also in the formation of one's personality. A society will always experience a transformation, but it is expected transformation of course is moving to a better and more usefull condition to human life. This is seen from the positive stimulus provided by the community, a positive impact also on changes in one's attitude. And the opposite is true, if the stimulus is negative, then the negative also the effect it produces.
\end{abstract}

Keywords:

Community Education, Srudent morals

\begin{abstract}
Abstrak : Tulisan ini bermaksud mengungkapkan seberapa jauh pengaruh pendidikan masyarakat pada perubahan akhlak remaja baik pada sisi sikap maupun mental. Persoalan ini diungkapkan dengan menggunakan studi kasus. Kasus yang dipilih adalah kasus pada masyarakat di Kampung Cisanggarung Kabupaten Bandung. Data dikumpulkan melalui wawancara, pengamatan dan studi dokumentasi serta dianalisis dengan metode Miles dan Huberman yang di landasi oleh teori akhlak Rasulullah SAW. Hasil penelitian menunjukan bahwa pendidikan masyarakat sangat berperan penting terhadap perubahan akhlak dan juga dalam pembentukan kepribadian seseorang. Suatu masyarakat akan selalu mengalami transformasi, namun yang diharapkan transformasi tentu saja adalah pindah ke kondisi yang lebih baik dan lebih berguna untuk kehidupan manusia ${ }^{2}$. Hal ini terlihat dari stimulus positif yang diberikan masyarakat, berdampak positif pula pada perubahan sikap seseorang. Dan berlaku kebalikannya, jika stimulusnya negatif, maka negatif pula pengaruh yang dihasilkan-nya.
\end{abstract}

\section{Kata Kunci:}

Pendidikan Masyarakat, Akhlak Siswa

\section{PENDAHULUAN}

Masyarakat adalah sekelompok orang yang membentuk sebuah sistem semi tertutup (atau semi terbuka), di mana sebagian besar interaksi adalah antara individuindividu yang berada dalam kelompok tersebut. Kata "masyarakat" sendiri berakar dari kata dalam bahasa Arab, musyarak. Menurut Syaikh Taqyuddin An-Nabhani, sekelompok manusia dapat dikatakan sebagai sebuah masyarakat apabila memiliki pemikiran, perasaan, serta sistem/aturan yang sama. Dengan kesamaan-kesamaan tersebut, manusia kemudian berinteraksi sesama mereka berdasarkan kemaslahatan.

Perubahan akhlak remaja yang begitu dinamis menuju kearah yang memprihatinkan dari waktu ke waktu menimbulkan rasa khawatir baik dikalangan orang 
tua, maupun dikalangan para pendidik. Karena remaja adalah calon generasi penerus kehidupan dan peradaban dalam sebuah Negara ataupun lingkungan masyarakat. Tentu saja para tokoh Negara ataupun masyarakat di suatu daerah tidak menghendaki jika rantai kehidupan berikutnya dilanjutkan oleh orang-orang yang tidak kompeten dalam segala hal, termasuk yang akhlaknya buruk. Karena sudah barang tentu cepat atau lambat akan membawa pada kehancuran.

Salahsatu hal yang berpengaruh pada pembentukan akhlak remaja adalah masyarakatnya itu sendiri, disamping dari orangtua dan lembaga pendidikan yang ditempuhnya. Kita bisa melihat apabila kehidupan di suatu daerah terlihat begitu menyenangkan, aman, tenteram, semua hal tertata dengan rapi, itu karena masyarakatnya saling menjaga dan mengingatkan akan pentingnya belajar menjaga sikap dan perbuatan. Sehingga para remaja yang ada di daerah itupun akan senantiasa belajar dari apa yang dilakukan oleh orang dewasa dan para orang tua mereka. Inilah yang dimaksud dengan Pendidikan Masyarakat.

Keadaan mental dan akhlak remaja yang ada di Kampung Cisanggarung menggambrkan adanya sejumlah persoalan yang harus segera diatasidan dicarikan solusi perbaikannya. Karena apabila dibiarkan begitu saja, akan membentuk mental dan akhlak yang jelek pada setiap remaja yang ada di kampung tersebut. Yang mana ujungujungnya akan berpengaruh ekali pada tata kelola kehidupan di kampung yang terletak di Desa Cikadut Kecamatan Cimenyan Kabupaten Bandung ini.

Pada pertengahan tahun 1998 ada sebuah kejadian yang terjadi di kampung Cisanggarung ii, dimana segerombolan pemuda dari kampung desa tetangga datang dengan menumpang pada dua mobil pick up, dengan tujuan menari seorang pemuda yang berdomisili di Kampung Cisanggaung. Namun karena pemuda yang dicari tidak ditemukan, (konon katanya pemuda yang dicari tersebut sudah kabur sebelum rombongan dari kampung tetanga tersebut datang) maka akhirnya mereka melampiaskan kekesalannya dengan menghancurkan sebuah rumah yang mereka kira adalah rumah dari pemda yang mereka cari. Padahal belakangan diketahui, rumah itu milik orang lain.

Ada juga kasus yang terjadi pada awal tahun 2017 kemarin, dimana salah seorang pemuda yang berasal dari kampung Cisanggarung yang bernama Kutil (nama samaran) ditangkap polisi dari Polsek setempat karena telah memukuli seorang pengendara ojek ingga babak belur, hanya karena pengendara ojek tersebut nekad melintas dan menerobos iring-iringan pertunjukan Seni Kuda Renggong yang sedang melakukan iring-iringan dijalan desa. Padahal dimana letak kesalahan pengendara ojek tersebut? Karena pada saat kejadian juga, dia di persilahkan melintas oleh petugas kemanan yang memang mengawal kegiatan iring-iringan tersebut. Tetapi Kutil malah menghajar pengendara tersebut dengan membabi buta. 


\section{METODOLOGI PENELITIAN}

Ditinjau dari objek dan kajian tempatnya, penelitian ini masuk kategori penelitian kepustakaan (library research), yaitu penelaahan yang dilakukan dengan cara mengadakan study terhadap buku-buku yang berkaitan dengan pokok permasalahan yang dibahas secara deskriptif analitik. Metode deskriptif dapat diartikan sebagai prosedur pemecahan masalah yang diselidiki dengan menggambarkan atau melukiskan keadaan subjek/objek penelitian (seseorang, lembaga, masyarakat dan lain-lain)

Jenis penelitian ini masuk dalam wilayah penelitian kualitatif yang dibahas secara deskriptif analitik dengan melalui pendekatan kualitatif rasionalistik yakni suatu pengetahuan yang diperoleh atas dasar pemahaman intelektual dan kemampuan argumentasi secara logika yang menekankan pemaknaan empirik

\section{HASIL KAJIAN DAN PEMBAHASAN}

Abad terakhir ini, kemajuan bidang pendidikan mencapai puncaknya dengan timbulnya konsepsi pendidikan baru yang berbeda dengan konsep pendidikan yang sudah ada dan telah lama berlangsung. Dalam konsepsi tersebut diketengahkan tentang Pendidikan Masyarakat yang merupakan sistem baru dalam dunia pendidikan. Pembahasan tentang Pendidikan Masyarakat memang merupakan hal yang menarik karena:

1. Pendidikan Masyarakat merupakan sistem baru dalam dunia pendidikan yang bentuk dan pelaksanaannya berbeda dengan sistem sekolah yang sudah ada.

2. Dalam Pendidikan Masyarakat terdapat hal-hal yang sama pentingnya bila dibandingkan dengan pendidikan luar sekolah. Seperti : bentuk pendidikan, tujuannya, sasarannya, pelaksanaannya dan sebagainya.

Dilihat dari segi tempat berlangsungnya kegiatan, pendidikan dapat terjadi dalam seluruh lingkungan kehidupan manusia. Proses pendidikan tidak hanya terjadi pada lingkungan keluarga dan lingkungan sekolah saja tetapi berlangsung pula pada situasi kehidupan yang lebih luas yaitu pada lingkungan masyarakat yang sering disebut juga sebagai pendidikan non formal. Berdasarkan Undang Undang Nomor 20 Tahun 2003 tentang Sistem Pendidikan Nasional, peristiwa pendidikan yang berlangsung pada lingkungan masyarakat tergolong pada pendidikan non formal.

Telah banyak pakar dan praktisi pendidikan memberikan definisi tentang konsep pendidikan non formal. Combes dalam Djudju S Sudjana (1989 : 29) mengemukakan pengertian formal dengan setiap kegiatan yang terorganisir dan sistematis di luar sistem persekolahan yang mapan, dilakukan secara mandiri atau merupakan bagian penting dari kegiatan yang lebih luas yang sengaja dilakukan untuk melayani peserta didik tertentu di dalam mencapai tujuan belajarnya

UNESCO dengan komisi Edgar Favre telah berhasil meletakkan asas pendidikan yang fundamental dan berlaku untuk penyelenggara pendidikan yakni asas pendidikan seumur hidup / long life education.

Sebagai dampak timbulnya asas pendidikan ini, maka dikenallah berbagai bentuk penyelenggaraan pendidikan dan yang diarahkan bagi pendidikan anak, remaja, orang 
dewasa maupun orang tua baik mereka yang belum bekerja maupun mereka yang telah bekerja.

Penyelenggaraan pendidikan demikian pasti berbeda satu sama lain dan pada umumnya dikenal berbeda sistem pendidikan yang digunakan, yakni sistem pendidikan sekolah, di satu pihak dan sistem pendidikan luar sekolah di pihak lain.

Sebagaimana asas pendidikan seumur hidup, sistem pendidikan luar sekolah telah lama dikenal dan digunakan dalam penyelenggaraan pendidikan baik di negara maju maupun negara yang sedang berkembang.

Secara terperinci dapat diungkapkan bahwa alasan-alasan timbulnya pendidikan luar sekolah adalah :

1. Alasan segi faktual-historis, meliputi :

a. Kesejarahan

b. Kebutuhan pendidikan

c. Keterbatasan sistem persekolahan

d. Potensi sumber belajar

e. Keterlantaran pendidikan seluar sekolah

2. Alasan dari segi analitis-perspektif, meliputi :

a. Pelestarian identitas bangsa

b. Kecenderungan belajar individual

3. Alasan dari segi formal-kebijakan, meliputi :

a. Pembukaan dan UUD 1945

b. Garis Garis Besar Haluan Negara

c. Pelita

Santoso S Hamidjojo (1982 : 18) mengemukakan bahwa pendidikan masyarakat atau pendidikan non formal bertujuan untuk membantu masalah keterlantaran pendidikan, baik bagi mereka yang belum pernah bersekolah maupun yang gagal (drop out) serta memberikan bekal sikap, keterampilan dan pengetahuan praktis yang relevan dengan kebutuhan hidup.

Dalam kerangka sistem pendidikan nasional, pendidikan non formal merupakan salah satu jalur yang bersama-sama dengan jalur pendidikan lainnya, mempunyai tujuan yang senantiasa mengarah pada tujuan pendidikan nasional. Sebagai salah satu jalur dalam sistem pendidikan nasional, pendidikan non formal mempunyai tujuan seperti ditegaskan dalam peraturan pemerintah nomor 73 tahun 1991 sebagai berikut.

1. Melayani warga belajar supaya dapat tumbuh dan berkembang sedini mungkin dan sepanjang hayatnya, guna meningkatkan martabat dan kehidupannya.

2. Membina warga belajar agar memiliki pengetahuan, keterampilan dan sikap mental yang diperlukan untuk mengembangkan diri, bekerja mencari nafkah atau melanjutkan pendidikan ke tingkat atau jenjang yang lebih tinggi.

3. Memnuhi kebutuhan belajar masyarakat yang dapat dipenuhi dalam jalur pendidikan sekolah. 


\section{SIMPULAN}

Dari berbagai uraian yang tersaji dalam tulisan ini dapat diambil suatu kesimpulan umum sebagai berikut :

1. Dilihat dari segi tempat berlangsungnya kegiatan, pendidikan dapat terjadi dalam seluruh lingkungan kehidupan manusia. Proses pendidikan tidak hanya terjadi pada lingkungan keluarga dan lingkungan sekolah saja tetapi berlangsung pula pada situasi kehidupan yang lebih luas, yaitu pada lingkungan masyarakat yang sering disebut juga sebagai pendidikan non formal. Berdasarkan Undang-Undang Nomor 20 tentang sistem pendidikan nasional, peristiwa pendidikan yang berlangsung pada lingkungan masyarakat tegolong pada pendidikan non formal.

2. Dilihat secara keseluruhan Pendidikan Masyarakat sangatlah berperan besar dalam pembentukan Sumber Daya Manusia. Hal ini bisa dimulai dengan mengarahkan akhlak remaja melalui Pendidikan Masyarakat. Tentu itu semua bisa berjalan dengan lancer dan berhasil dengan baik apabila ada kerjasama dan rasa tanggung jawab dari semua unsur masyarakat.

\section{DAFTAR PUSTAKA}

Hasbiyallah, "Transformation of the Education of Moderate Muslim Society: A Thought Study of Nahdlatul Ulama”. Jurnal Pendidikan Islam :: Volume 6, Nomor 1, June 2017/1438

Nurteti, Lilis, M.Pd. 2010. Pedagogik Pengantar Analisis. Ciamis. IAID.

Joesoef, Soelaiman, Prof. Dr. 1986. Konsep Dasar Pendidikan Luar Sekolah. Bumi Aksara.

Departemen Sosial RI. 1986. Perkembangan SLD. Jakarta.

Undang Undang Republik Indonesia Nomor 20 Tahun 2003 tentang Sistem Pendidikan Nasional. 2005. Jakarta. 